\title{
Analysis of the seismic site effects along the ancient Via Laurentina (Rome)
}

\author{
Francesca Bozzano $^{1}$, Anna Buccellato ${ }^{2}$, Fulvio Coletti ${ }^{2}$, Salvatore Martino ${ }^{1}$, Fabrizio Marra ${ }^{3}$, \\ Stefano Rivellino ${ }^{1}$, Chiara Varone ${ }^{1, *}$ \\ ${ }^{1}$ Research Centre for Geological Risks (CERI), University of Rome "La Sapienza", Rome, Italy \\ ${ }^{2}$ Soprintendenza speciale per il Colosseo, Museo Nazionale Romano e Area Archeologica di Roma, Rome, Italy \\ ${ }^{3}$ Istituto Nazionale di Geofisica e Vulcanologia, Rome, Italy
}

\author{
Article history \\ Received September 1, 2016; accepted May 10, 2017. \\ Subject classification: \\ Seismic site effects, numerical modelling, Ancient Via Laurentina, Rome
}

\begin{abstract}
This paper presents an evaluation of the Local Seismic Response (LSR) along the route of the ancient Roman road Via Laurentina, which has been exposed in several areas of southwest Rome over the last decade during the construction of new buildings and infrastructures. It is an example of LSR analysis applied to ancient and archaeological sites located in alluvial valleys with some methodological inferences for the design of infrastructure and urban planning. Since the ancient road does not cross the alluvial valley (namely the Fosso di Vallerano Valley) normal to its sides, it was not possible to directly perform $2 D$ numerical modelling to evaluate the LSR along the road route. Therefore, outputs of 2D numerical models, obtained along three cross sections that were normal oriented respect to the valley, were projected along the route of the Via Laurentina within a reliable buffer attributed according to an available high-resolution geological model of the local subsoil. The modelled amplification functions consider physical effects due to both the $2 D$ shape of the valley and the heterogeneities of the alluvial deposits. The $1 D$ and $2 D$ amplification functions were compared to output that non-negligible effects are related to the narrow shape of the fluvial valley and the lateral contacts between the lithotecnical units composing the alluvial fill. The here experienced methodology is suitable for applications to the numerical modelling of seismic response in case of linear infrastructures (i.e., roads, bridges, railways) that do not cross the natural system along physically characteristic directions (i.e. longitudinally or transversally).
\end{abstract}

\section{Introduction}

Several studies, focused on local seismic response in Rome [Bozzano et al. 2008, Bozzano et al. 2012, Bozzano et al. 2016, Caserta et al. 2012, Martino et al. 2015]; [Rovelli et al. 1994, 1995], have already highlighted that the urban areas can be affected by amplification of seismic shaking. The heterogeneous compo- sition of the alluvial deposits of the Tiber River and its tributaries is responsible for both 1D amplification effects, which are mainly related to soil stratigraphy and 2D amplification effects, which can be related to wave refraction at the edge of the valley as well as lateral heterogeneities [Martino et al. 2015]. While 1D amplification can be evaluated by simple 1D numerical simulations, to evaluate the 2D amplification, the numerical models should take into account the effects related to the shape of the valley and the lateral heterogeneities of the alluvial deposits.

This study focuses on the Local Seismic Response (LSR) along the ancient Roman road Via Laurentina (Figure 1), which was recently excavated in the Fosso di Vallerano Valley, a left tributary valley of the Tiber River. In the literature, the identification of the Via Laurentina has long been considered secondary to the question of the existence of Laurentum and has been linked to the hypothesis of two roads leading to the coast, both of which branch off from the Via Ostiense road. The western road is thought to correspond to the line formed by the Via Pontina Vecchia road (which replaced the Via di Decima road in the 1930s) and the Via di Pratica road. The eastern road initially corresponds to the modern Via Laurentina road, then follows the Via di Trigoria road and finally joins the Via di Pratica road in the direction of Lavinio. The identification of Laurentum with Lavinium and Castagnoli's identification of the town as the Vicus Augustanus Laurentium of later written sources has favoured the recognition of the Via Laurentina as the road that leads to the town of the Laurentes, which is Lavinium, the former route being that followed by the Via Pontina Vecchia road. The iden- 

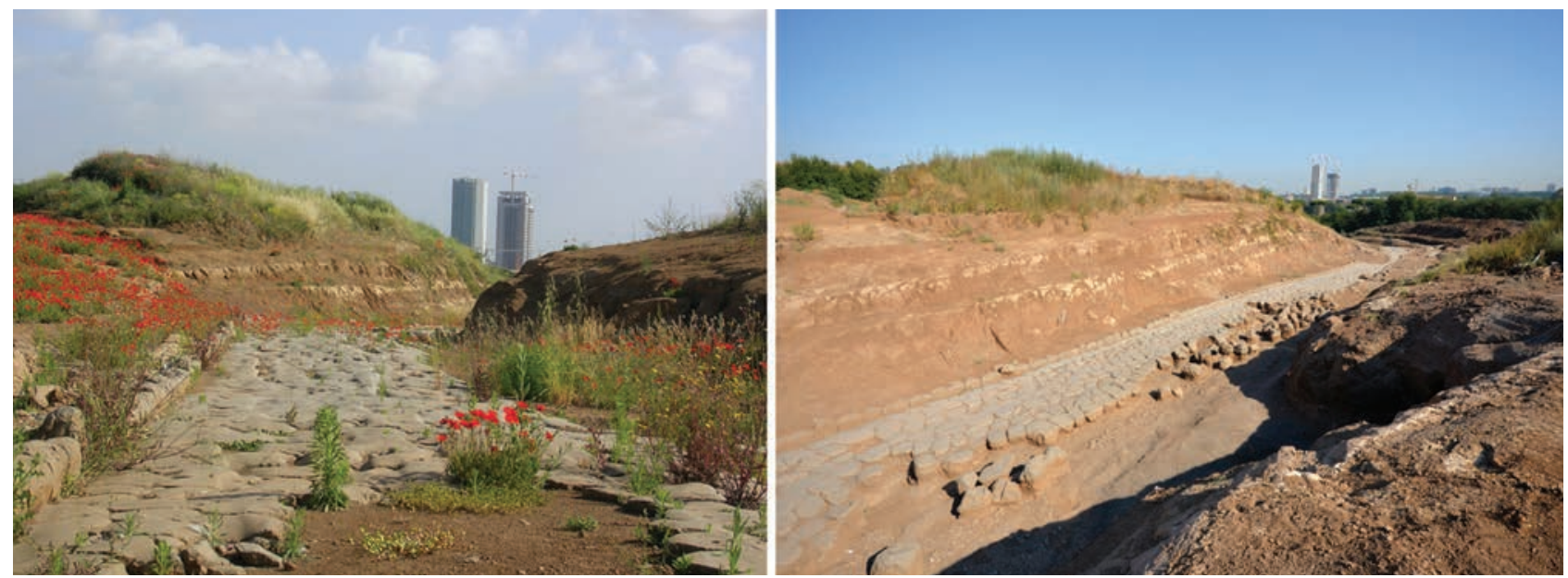

Figure 1. Views (from S) of the Via Laurentina road (mile 6). The two towers of the "Europarco Business Park" can be seen in the background.

tification of the town was later confirmed by evidence from excavations conducted by the "Soprintendenza Speciale per il Colosseo il Museo Nazionale Romano e l'Area Archeologica di Roma" (SSCOL), MNR (Museo Nazionale Romano) and "Area archeologica di Roma", between 2007 and 2016, which documented the typical characteristics of the viae publicae. In particular, Virgilian records state that the route crosses the valley of the Fosso di Vallerano basin, ascends a tufa ridge in the Tor De' Cenci estate and descends through the valley of the Malafede River to the coast; it runs NNE-SSW and cuts all the other valleys at a significant angle with respect to the river courses [Ascani et al. 2008 and references within]. The choice of this route for the road, which implies in-depth knowledge of the territory during the Roman period and even in the proto-historic period, was based on linking routes from Castel di Decima, probably Tellenae, which was one of the autonomous centres of Latium Vetus that, according to Pliny, were destroyed by Ancus Marcius during Rome's expansion toward the coast.

In the Fosso di Vallerano Valley, the road is interesting in terms of the LSR because the ancient route does not cross the fluvial valley normal to the valley sides, which is the expected orientation of $2 \mathrm{D}$ effects due to the interaction between the main resonance and lateral seismic waves [Bard and Bouchon 1985]. As a result, a $2 \mathrm{D}$ numerical model of a representative geological cross section of the ancient Via Laurentina route cannot represent the real $2 \mathrm{D}$ response that can occur along a section that is oriented normal to the sides of the valley. To provide a suitable solution to this problem, several cross sections that were oriented normal to the valley were analysed to determine the "physically-based" seismic response of the natural system, and the results were applied to the route of the ancient road by pro- jecting them based on an engineering-geological model of the site. The aim of this study is to propose and demonstrate a reliable methodology that can be applied to seismic response evaluations of linear infrastructure (i.e., roads, bridges, railways) that do not cross the natural system along physically characteristic directions (i.e. longitudinally or transversally). In the case of archaeological structures that are mainly linear (e.g., aqueducts, bridges or walls), such an approach can contribute to their preservation and resilience to expected seismic events.

\section{Archeological setting of the ancient Via Laurentina}

The excavations that have been carried out by SSCOL have exposed more than one kilometre of the road and have documented the characteristics of the major Roman roads and the interventions that were necessary for their management, including:

1. land reclamation, excavation of trenches and dumps of earth and gravel;

2. a road bed width of at least $4 \mathrm{~m}$ to allow the simultaneous transit of carts in both directions;

3. construction on foundation layers of large stones (rudus) and a core of crushed stone and paved with perfectly abutting polygonal basalt blocks that form a crowned surface. The roadbed is bordered by edge stones (umbones) that are placed with the flat face on the interior and the wedged side facing outwards, which contained the sidewalks of beaten gravel. Gonphi, which were taller stones that prevented the carts from mounting the sidewalks and helped travellers to get on and off the carts, were spaced along the sidewalks.

Sections paved with earth with a gravel surface (glareata) or basalt, which can be dated to the first century of the empire based on the associated funerary 


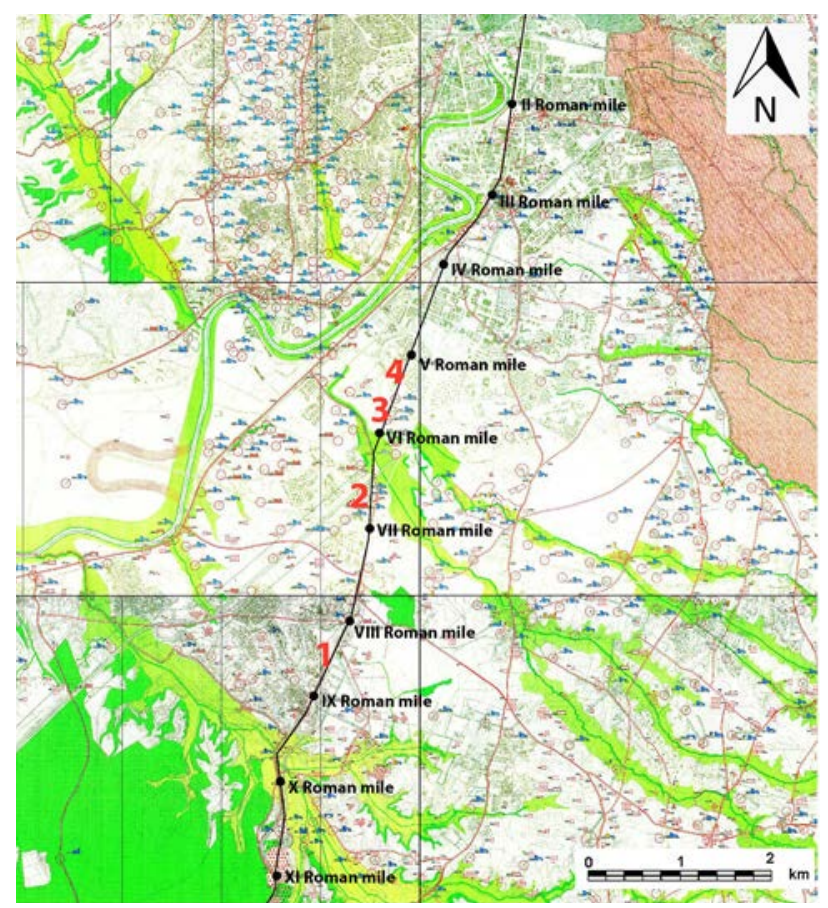

Figure 2. Map of the common "agro romano": route of the ancient Via Laurentina, with Roman milestones (black line); the red numbers indicate the sites in Figure 3.

contexts, are present in several areas. Starting from the south between miles 8 and 9 (Figure 2) below the Via Pontina road outside the highway Grande Raccordo Anulare (near the junction with the Via degli Eroi di Cefalonia), two levels of paving were documented at $52.55 \mathrm{~m}$ a.s.l. for a length of c. $150 \mathrm{~m}$, which show evidence of intense traffic and maintenance work. In both phases, the road, which was between 4 and $6 \mathrm{~m}$ wide, was composed of a bed of stone chips mixed with gravel that was bordered by two rows of basoli and was contained within two opus reticulatum structures, which were built to protect the road from the effects of ground wash (Figure 3, frame 1) [Buccellato 2005].

The section between miles 5 and 6 was crucial for the identification and recognition of the structural and infrastructural characteristics (Figure 3, frame 2). The segment that was discovered on a rise, near the point where the modern Via Decima and Via Pontina roads meet, represents the earliest evidence of the road from the late Archaic period. In the southern sector, which runs along a ridge, the earliest phase of the road surface that can be identified from cart tracks that are directly on a layer of pyroclastic material can be dated to the late Archaic - early Republican periods based on the stratigraphic sequence and the typology of two chamber tombs in the eastern wall of the road cut. The third level, which had an earth and gravel surface and was dated to the $2^{\text {nd }}$ century B.C. based on the discovery of a coin, revealed restructuring work, including the rectification of the axis and the use of more complex technical solutions, to which the inscription probably refers. Further numismatic evidence dates the re-laying of the road surface to after the $2^{\text {nd }}$ century B.C. The new surface was composed of gravel bonded with mortar and was raised by the use of a substantial layer of leucitite stones and was partially supported with tufa blocks in a depression. The northern sector of the final level, which includes basalt paving that dates to the Julio/Claudian period, represented an important structural work that indicates that geometric and geological criteria were used to calculate the line of the road. The saddle within which the road formed a sharp bend was artificially transformed into a large cut that was 15 to $20 \mathrm{~m}$ wide at the summit and $9 \mathrm{~m}$ wide at the base. The walls are vertical or terraced in layers of pozzolan sediments that alternate with paleo-soils, while in the lower levels, the clays are up to $5 \mathrm{~m}$ high. This allowed the route from the hill at $35.38 \mathrm{~m}$ a.s.l. to connect to the plain that leads to the Castellaccio Valley at $21.38 \mathrm{~m}$ a.s.l. with a gradient of $13 \%$. The northern part passed through a ravine that showed substantial anthropic activity.

The road showed several signs of use. The cart tracks have an average inter-axis width of $1.4 \mathrm{~m}$. The width of the road increased from $4.1 \mathrm{~m}$ to $6 \mathrm{~m}$ in the steeper segments to allow vehicles to pass each other and at stopping points near funerary areas. Inside the cut, the road was flanked on the east by segments with leucitite paving, which was mainly for pedestrian use. At mile 5, which is below the present Via di Decima and Via dell'Acqua Acetosa Ostiense roads, the first stretch was $4.20 \mathrm{~m}$ wide, paved in perfectly adhering basalt polygons, and bordered by a row of basoli placed on edge (umbones, including a gomphus) and a 1.30-m-wide sidewalk made from stone chips. The second segment, which is $20 \mathrm{~m}$ long, showed evidence of a later restoration, was up to $6 \mathrm{~m}$ wide, and indicates the importance of the route even in a period of general abandonment that can be correlated with the shift of the economic epicentre away from the Ostiense area by Constantine. Descending into the Fosso di Vallerano basin in the alluvial plain of the Ciuccio, Acqua Acetosa and Vallerano creeks, which are tributaries of the Tiber, a straight stretch of the road that is approximately $500 \mathrm{~m}$ long was exposed at Castellaccio [Buccellato 2007, Buccellato and Coletti 2013 and references within]. It showed several levels of construction and maintenance from the Archaic to late antique periods, which documented the organisational and technical efforts of the Roman State, particularly regarding the need to keep the roadbed above the water table (Figure 3, frame 3). 

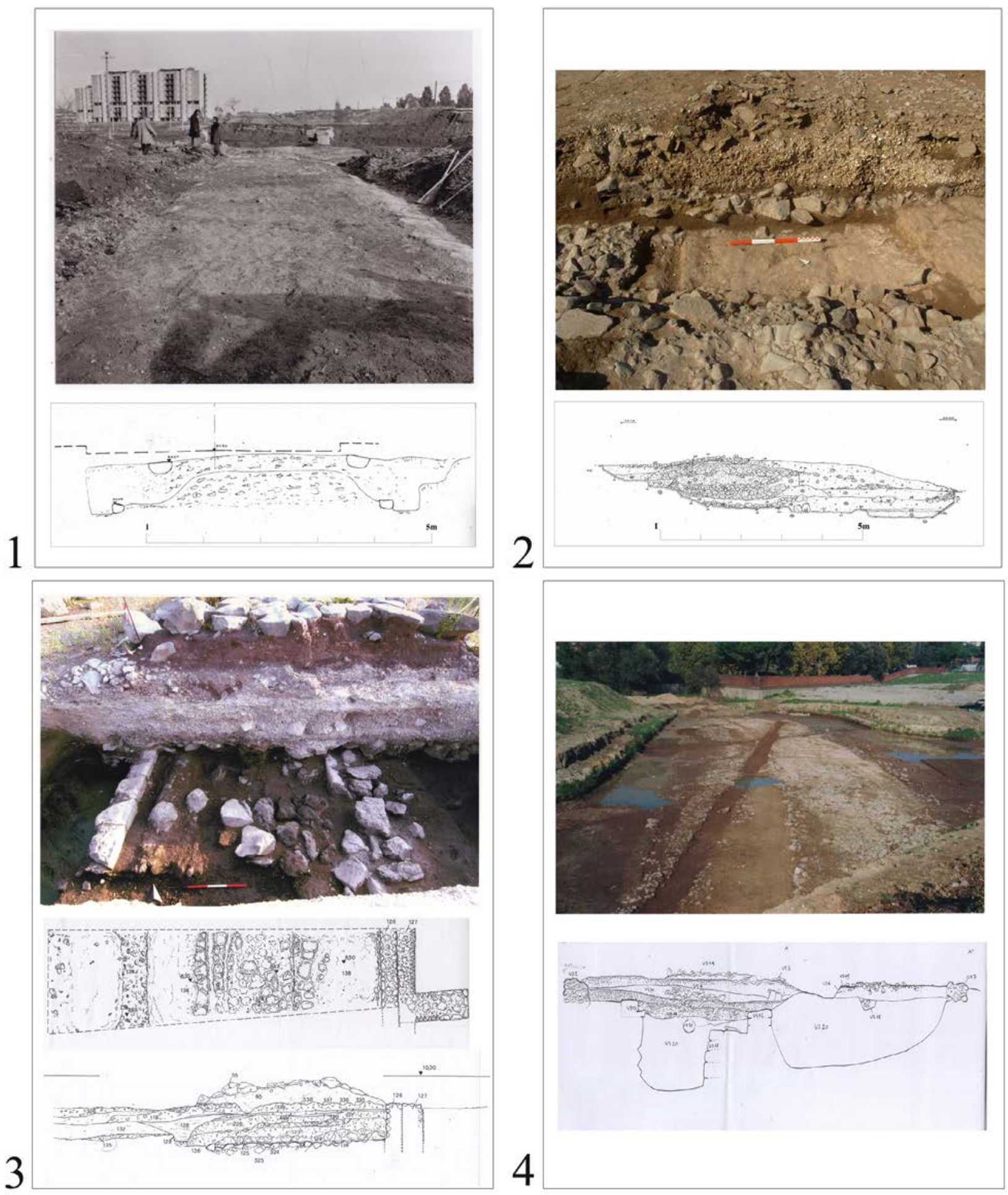

Figure 3. (1) Intersection of the Via Pontina road with the Via degli Eroi di Cefalonia road: photo and section of street levels; (2) intersection of the Via Pontina road with the Via di Decima road: photo and section of street levels; (3) basin of the Fosso di Vallerano (loc. Castellaccio): photo, planimetry and section of street levels; 4. basin of the Fosso di Vallerano: photo and section of street levels.

Stratigraphic relationships indicate that the first level, which had a paved of earth and gravel surface, was in use in the $2^{\text {nd }}$ century B.C., but it was probably in use as early as the late $4^{\text {th }}$ century B.C., as was suggested by the first phase of an important necropolis and the rural building located at the junction with a branch road. During the 1st century B.C., a substantial new, raised road surface of earth and gravel, which was supported by an opus incertum wall, was built. A more technically complex intervention occurred in approximately the middle of the 1st century A.D.; the road surface, which was an average of 6 $\mathrm{m}$ wide, was raised and paved with basalt polygons, which were contained by opus reticulatum walls that were buttressed at regular intervals. In addition, infrastructure that was probably made of timber made up 
a land drainage system for the catchment area of the three tributaries of the Tiber. This regimentation of the Acqua Acetosa stream, which has been identified across the entire plain, was intended to reclaim the areas that were subject to flooding and to drain the floodwaters of the Tiber. The infrastructure consisted of the improvement of the riverbanks with a lining of opus reticulatum that was c. $2 \mathrm{~m}$ high. The road, which ran north-south, crossed the river in the stretch that is presently buried by an arched bridge, of which only the brick parapets survive, that was presumably built as part of the restoration in 177 A.D. based on an inscription that refers to Marcus Aurelius or Commodus. The strict spatial and functional correlation with the Acqua Acetosa River, which is identified with the border of the ager romanus antiquens, denotes cult interest from proto-historic times at the site. Based on the milestones that begin at the Servian walls, this site is located within the $6^{\text {th }}$ mile, where sources record the presence of the ancient sanctuary of the god Terminus, which was the site of the celebration of the Terminalia or lustratio of the borders. This was one of the cults and sanctuaries that were located along the roads that led into the city and delimited the urban territory as early as the late $8^{\text {th }}$ or early $7^{\text {th }}$ centuries B.C. The interventions by the Roman State, which had been defined by maintenance and rebuilding, now turned to the creation of infrastructure. This is indicated by the presence of a necropolis along the road, which was dated to the Republican and imperial periods, by a rural building that dates to between the $4^{\text {th }}$ and $2^{\text {nd }}$ centuries B.C. at the location where the Via Laurentina met a secondary road that headed east along the original line of the Acqua Acetosa Ostiense ditch, and by a large architectural complex that covers c. $1380 \mathrm{~m}^{2}$ along the stretch where the basalt paving is preserved. Finally, like all of the consular roads, the Laurentina was flanked by a necropolis that covered c. $1000 \mathrm{~m}^{2}$ and included more than 250 tombs, mainly inhumation burials and some cremations. The stratigraphy of the burial levels and analyses of the grave contents indicate at least three phases of use between the late $4^{\text {th }}$ and early $3^{\text {rd }}$ centuries B.C. and during the first two centuries of the Empire. The road was rebuilt in the late antique period, between the $3^{\text {rd }}$ and $4^{\text {th }}$ centuries, by reusing the surface from the $2^{\text {nd }}$ century. This temporary intervention, which was limited to a few stretches, narrowed the road to $4.50 \mathrm{~m}$ wide, removed its borders and shifted the central axis with respect to the original line. During subsequent periods until the Middle Ages, parts of the road earthwork fell into disuse and were radically altered and heavily robbed for construction materials (Figure 3, frame 4). A final 50-m-long stretch was uncovered on the edge of the urbanised area of EUR quarter, which has compromised the preservation of the ancient road. This section documents the interventions that were performed on the earliest levels of the road that date to the early Republican period, including an increase in the level of the road surface to $8.97 \mathrm{~m}$ a.s.l. with rows of tufa blocks up to one metre high that rest directly on sterile soil. Through various reconstructions, the third earth and gravel road, which dates to the early imperial period, was $6 \mathrm{~m}$ wide and was supported by the canonical structure, contained by rows of stones and flanked by sidewalks.

\section{Geological setting}

The city of Rome is located on the coast of the Tyrrhenian Sea in Central Italy, SW of the Apennine mountain chain, and is crossed by the Tiber River. After the main development of the central Apennine thrust and fold belt, crustal extension has affected the area of Rome since the late Messinian due to the development of the Tyrrhenian back-arc basin [Parotto and Praturlon 1975]; [Sani et al. 2004]. Neo-autochthonous marine sedimentation occurred from the Pliocene to the early Pleistocene, which led to the deposition of the two transgressive cycles of Monte Vaticano and Monte Mario Formations [Bonadonna 1968, Conato et al. 1980, Marra 1993, Marra and Rosa 1995]; [Cosentino et al. 2009]. Since the late Pliocene, continuous regional uplift has caused the progressive shift to continental sedimentation that is provided by a primitive drainage network controlled by the paleo-Tiber River [Marra and Florindo 2014]. The area around Rome has hosted the delta of the paleo-Tiber River since the Middle Pleistocene [Milli et al. 2013], and its geologic evolution is the result of complex geological processes, including tectonics, volcanism and glacio-eustatic fluctuations [Karner et al. 2001, and references therein]. The continental to coastal sedimentary successions of the paleo-Tiber River have been deposited since $800 \mathrm{ka}$ in response to sea-level rise during the Pleistocene glacial terminations, which have been demonstrated by a series of recent studies that used the $40 \mathrm{Ar} / 39 \mathrm{Ar}$ ages of tephra intercalated within the sedimentary deposits to provide geochronologic constraints that link these aggradational successions to the Marine Isotopic Stages (MIS) [Karner and Renne 1998]; [Karner and Marra 1998]; [Marra et al. 1998]; [Florindo et al. 2007]; [Marra and Florindo 2014]; [Marra et al. 2016]. The aggradational successions near Rome therefore represent a discontinuous stratigraphic record that is composed of a succession of ten major aggradational 


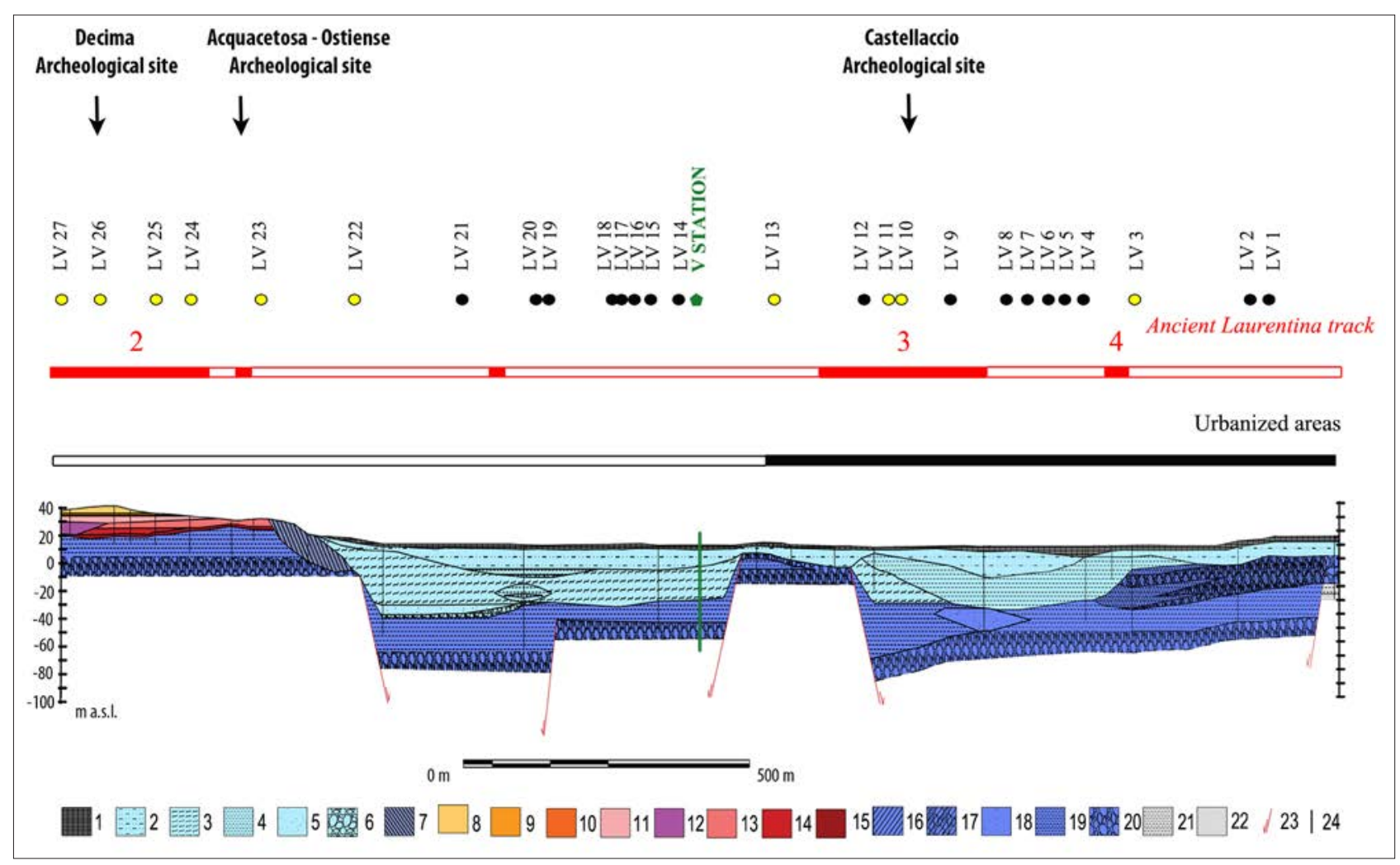

Figure 4. Geological cross section along the route of the ancient Via Laurentina (shown in Figure 7). Legend: recent alluvial deposits: 1) anthropic filling material (AL-AF); 2) sandy clays characterized by a significant volcanic component (AL-VSC); 3) peaty clays (AL-PC); 4) clays and silts (AL-CS); 5) sands and silty sands (AL-SD); 6) polygenic and heterometric gravels (AL-GR). Pre-Wurmian deposits (Valle Giulia - San Paolo - Aurelia - Vitinia Formations): 7) fluvio-palustrine deposits composed of loose gravels, sands and silts (FL). Volcanic deposits from the Alban Hills District (VC): 8) Pozzolanelle; 9) Pozzolane Nere; 10) Conglomerato Giallo; 11) Pozzolane Rosse; 12) Vallerano lava; 13) Tufo Terroso con Pomici Bianche; 14) Tufo del Palatino; 15) Tufo Pisolitico di Trigoria. Paleo-Tiber 4 deposits (Santa Cecilia Formation): landslide deposits: 16) clay and silty clay (PT-LS, CL) 17) loose gravels (PT-LS (GR)); 18) sands and silty sands. (PT-SD); 19) clays and silts with peaty layers (PT-CL); 20) loose gravels (PT-GR). Plio-Pleistocene bedrock (Marne Vaticane - Monte Mario - Monte delle Piche Formation): 21) marine clays and silty clays; 22) marine sands and silty sands. 23) Fault. 24) Borehole. The black marker indicates the urbanized portion of the cross section, and the red marker indicates the discovered portion of the ancient Via Laurentina. Red numbers indicate the locations of the photos shown in Figure 3. The locations of the noise measurement points and seismic station $V$ are also indicated.

units that were deposited during MIS 22-21 thorough MIS 2-1 and several minor successions that correspond to the more pronounced sub-stages and represent the physical remnants of the glacio-eustatic sea-level cycles during this time period. These successions fill the fluvial valleys and the coastal plain incisions that were excavated during the sea-level lowstands and interfinger with the pyroclastic products of the Colli Albani and Monti Sabatini Volcanic Districts, whose activity

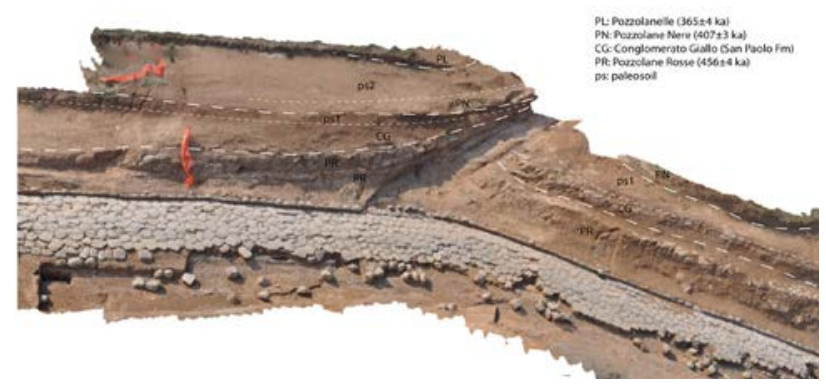

Figure 5. Photo of the Decima archaeological site. The outcropping volcanic formations are labelled, and the stratigraphc limits are shown by the dashed white lines. spanned 600-20 ka [Marra et al. 2009, 2014]; [Gaeta et al. 2016 and references therein]. A thick succession of pyroclastic flow deposits and subordinate air-fall deposits interfingers with the continental sediments that were deposited within palaeovalleys during periods of sea-level rise, which caused significant lateral and vertical facies variability. Since the Middle Pleistocene, the volcanic activity has been mainly responsible for the present landforms in terms of the production of rocks that shape the natural landscape, particularly on the left side of the Tiber River [Del Monte et al. 2013]. However, after the most recent volcanic activity in the Upper Pleistocene, the volcanic plateau was deeply incised during the Last Glacial Maximum, and the palaeovalleys were then filled by thick packages of fluvial deposits [Bozzano et al. 2000, Mancini et al. 2013, Marra et al. 2013].

According to Bozzano et al. [2016], 4 main lithostratigraphic groups were identified in the Fosso di Vallerano valley area: 


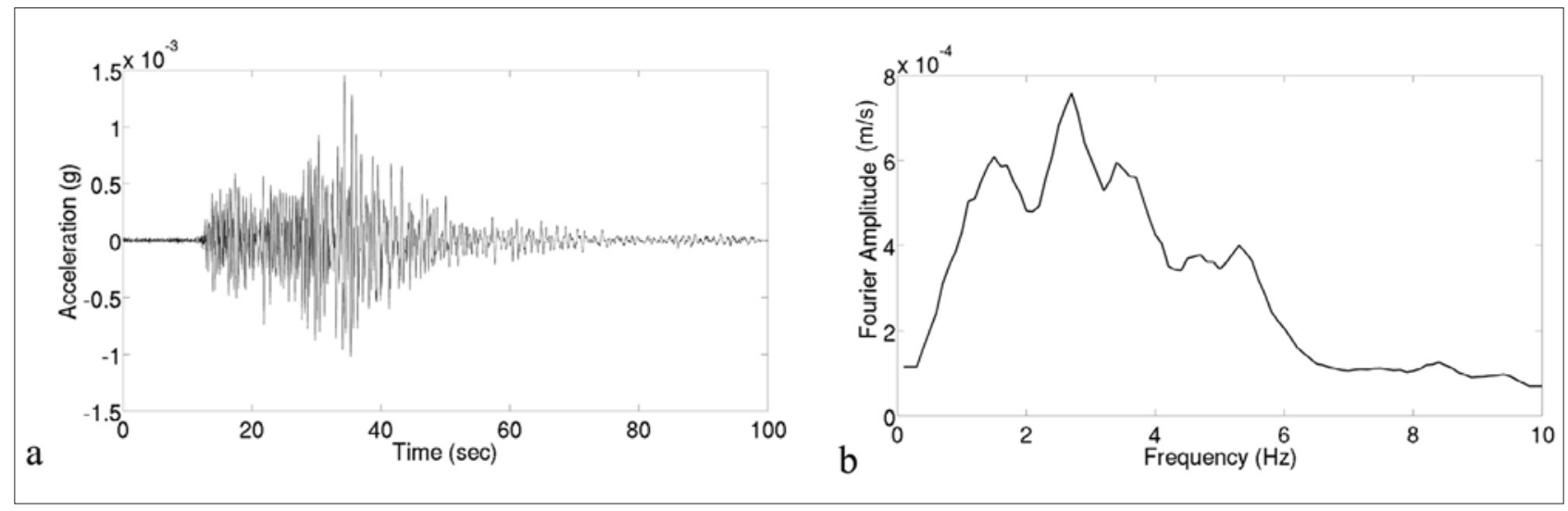

Figure 6. Time-history (a) and Fourier spectrum (b) of the earthquake recorded at the Fosso di Vallerano valley on 23 June 2009 here used for the visco-elastic numerical modelling.

- Plio-Pleistocene marine sediments (PP) (Marne Vaticane, Monte Mario and Monte Ciocci/delle Piche Formations) that represent the geological bedrock;

- Pleistocene alluvial sediments deposited by the paleo-Tiber River (PT) (Santa Cecilia Formation; 650-600 ka; Marra and Florindo, [2014];

- Volcanic deposits that erupted from the Alban Hills and the Monti Sabatini Volcanic District (VC) (561-365 ka);

- Recent alluvial deposits that have filled the incised valley from the end of the Würmian regression to the present (AL) (18 ka-Present);

A geological cross section (Figure 4) was derived just along the route of the ancient Via Laurentina as reconstructed by SSCOL (Figure 7). This section is therefore not geometrically cut respect to the valley and its direction continuously changes depending on the route of the ancient Roman road. The southern part of the section corresponds to an inhabited area (Torrino hill) that is characterized by the presence of VC deposits. To the north, the section crosses the alluvial plain of the Fosso di Vallerano Valley. This portion is characterized by AL deposits that overlap the PT deposits, which results in a horst and graben structural setting due to the synsedimentary Pleistocene tectonic activity.

Along the track of the ancient Via Laurentina that corresponds to the Decima archaeological site, a portion of the Alban Hill volcanic sequence outcrops because of the excavation of the hill during the construction of the ancient Via Laurentina (Figure 5).

\section{Geophysical data}

As reported by Bozzano et al. [2016], from June until July 2009, a free-field seismic array in Short Time Average to Long Time Average (STA/LTA) acquisition mode was installed in the Fosso di Vallera- no Valley to record weak-motion events during the tail of the L'Aquila seismic sequence. The array was composed of two stations (Figure 7) that were instrumented by three single component $1 \mathrm{~Hz}$ velocimeters (SS1 Kinemetrics), which were triaxially arranged and connected to a 24 bit data logger (K2 Kinemetrics) and a GPS device for absolute timing. One station $(\mathrm{V})$ was located on the alluvial deposits in the NE part of the valley (Figure 7), while a reference station $(\mathrm{R})$ [sensu Borcherdt 1994] was located on seismic bedrock in the volcanic hills that border the valley (Figure 7). The seismic array recorded approximately 30 earthquakes with magnitudes from 2.6 to 4.6 . A 5\% cosine-taper window starting $1 \mathrm{~s}$ before the P-phase onset was applied to the earthquake records to obtain signals with durations of $100 \mathrm{~s}$. The signals were converted to the frequency domain and pass-band filtered in the frequency range of $0.2-10 \mathrm{~Hz}$. One of the earthquakes

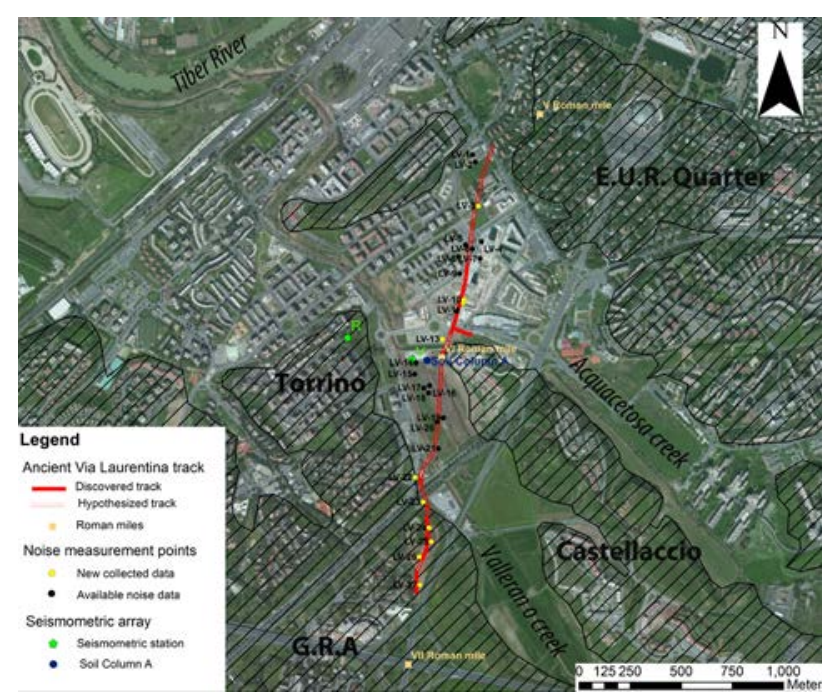

Figure 7. Location of the ancient Via Laurentina road in the southern part of Rome and sites of noise measurements along the route. The shaded areas correspond to outcrops of seismic bedrock. $\mathrm{V}$ and $\mathrm{R}$ indicate the seismic stations on alluvial deposits and seismic bedrock, respectively. 

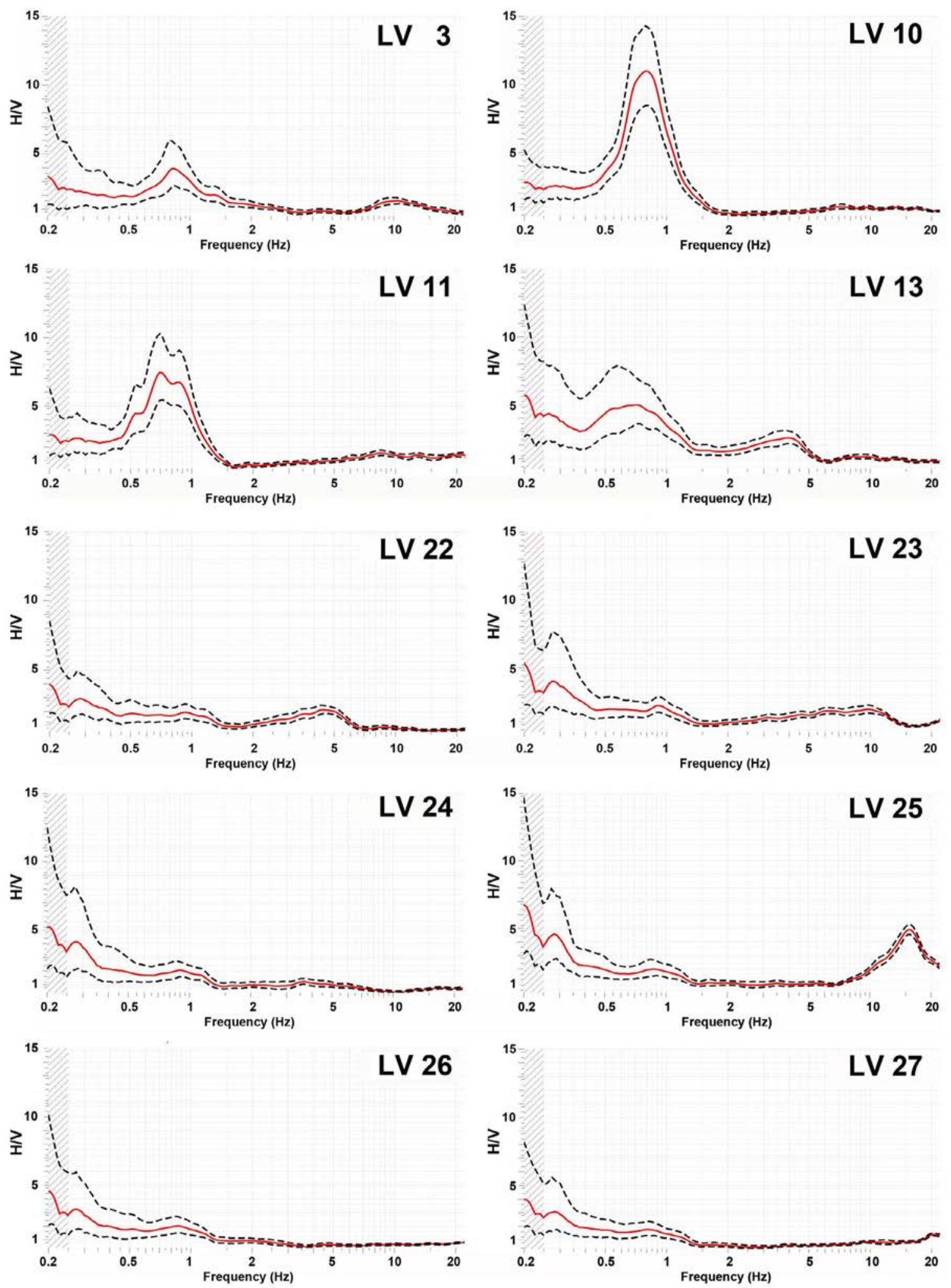

Figure 8. Results of H/V measurements at 10 sites along the ancient Via Laurentina. Red line: average H/V spectral ratio; dashed black lines: standard deviation of the $\mathrm{H} / \mathrm{V}$ spectral ratio; dotted zone: unreliable frequency range of the H/V spectral ratio.

that were recorded at the $\mathrm{R}$ station was used for the numerical modelling of the LSR along the route of the ancient Via Laurentina (Figure 6).

To quantify the local seismic amplification along the route of the Via Laurentina, seismic noise measurements from previous studies were collected [Bozzano et al. 2016], and a new campaign of geophysical measurements was performed, including 13 meas- 


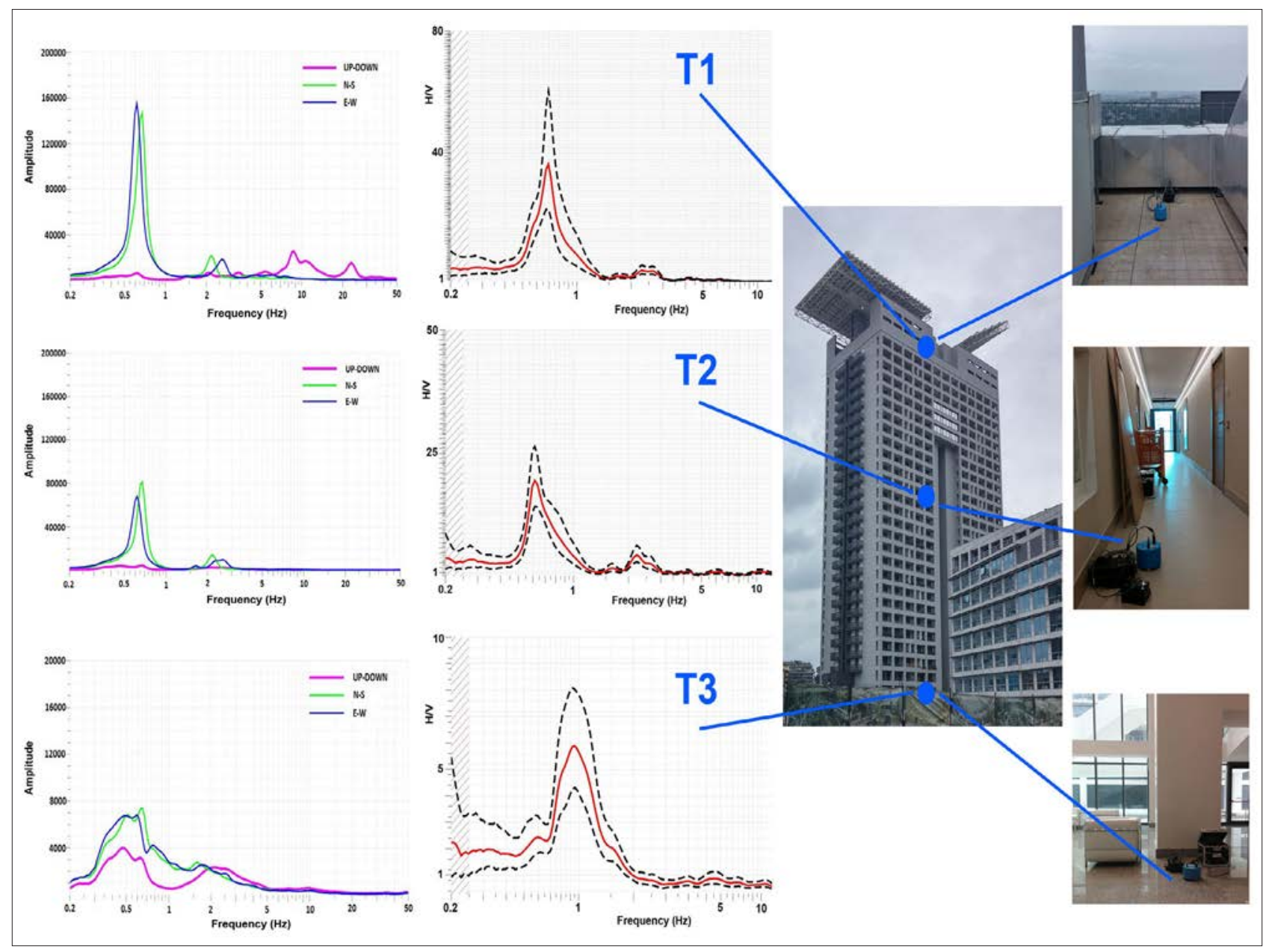

Figure 9. Results of noise measurements (Fourier Spectra and H/V) performed on the north Eurosky tower. T1: roof; T2: middle floor; T3: ground floor. Note the attenuation of the peak amplitude from the top of the tower to the bottom and the shift of the peak frequency from the vibration mode of the tower (T1 and T2) to the site main vibration (T3). Red line: average H/V spectral ratio; dashed black lines: standard deviation of the H/V spectral ratio; dotted zone: unreliable frequency range of the H/V spectral ratio.

urements at excavated sites along the Via Laurentina as well as locations where the presence of the road has been hypothesized (Figure 7).

The investigations were performed using a REFTEK 130 (24 bit) data logger with a Lennartz $5 \mathrm{~s}$ seismometer. The records were obtained for approximately 1 hour at a sampling rate of $250 \mathrm{~Hz}$ and processed according to the technique of Nakamura [1989] and the SESAME [2004] standard using the open source software GEOPSY and the following analysis procedure:

- subdivision of each time series in $40 \mathrm{~s}$ windows with overlaps of $25 \%$;

- correction, tapering to $5 \%$, calculation of the Fast Fourier Transform (FFT) and smoothing of the spectrum for each window using the algorithm of Konno and Omachi [1998] with the b parameter equal to 40 ;

- calculation of the amplitudes of the three spectral components (N-S, W-E, up-down $(\mathrm{V})$ ), the geometric mean $(\mathrm{H})$ between the two horizon- tal components and the spectral ratio $(\mathrm{H} / \mathrm{V})$ in each time window;

- calculation of the average spectral amplitudes for the three components and the average spectral ratio $(\mathrm{H} / \mathrm{V})$ in all of the selected time windows; - directional analysis of the site response through the graphical representation of the $\mathrm{H} / \mathrm{V}$ values as functions of frequency and azimuth.

A total of 27 noise measurements (see examples in Figure 8) were available along the analysed route of the Via Laurentina across the Fosso di Vallerano Valley. The results of the new campaign well fit the geological model of the valley:

- in the southern portion of the route, the processed data (LV_27, LV_26, LV_25 and LV_24 in Figure 8) show no amplification. This result is related to the outcrops of the volcanic units and the presence of shallow seismic bedrock (approximately $30 \mathrm{~m}$ below the soil level) without a significant impedance contrast;

- in the middle part, no clear peaks are present on 
the average $\mathrm{H} / \mathrm{V}$ spectral ratio $\left(\mathrm{LV} \_23\right.$ in Figure 8) except for site LV_22, which has an amplification peak at $4.5 \mathrm{~Hz}$ related to a shallow impedance contrast.

- in the northern portion of the route, all of the processed data show a clear stratigraphic peak at $0.8 \mathrm{~Hz}$ (LV_3 and LV_10 in Figure 8) or between 0.7 and $0.9 \mathrm{~Hz}$ (LV_11, and LV_13 in Figure 8) due to the strong impedance contrast between the alluvial deposits that fill the valley (up to 60 meters thick) and the basal gravels. Such a contrast, already observed and discussed by Bozzano et al. [2016] for the Fosso di Vallerano valley as well as by Martino et al. [2015] for the Tiber river valley in the historical centre of Rome, justifies that the seismic bedrock generally does not coincide with the geological one in the alluvial context of the Rome urban area. In the northern part of the route, the only exception to the above described local seismic response consists in the spectral ratio $(\mathrm{H} / \mathrm{V})$ resulting at station $L V \_13$, which includes a weak peak at approximately 4 $\mathrm{Hz}$ that is likely due to a local and shallow horst in the seismic bedrock.

It is worth noting that the significant resonance peak at LV_10 derives from a strong site energization at frequencies of 0.6 to $0.8 \mathrm{~Hz}$, which is likely induced by the vibration mode of the nearby towers (Figure 9). To verify this effect, $\mathrm{H} / \mathrm{V}$ seismic noise measurements were performed on the north Eurosky Tower (top (T1), middle (T2) and base (T3) in Figure 9). The

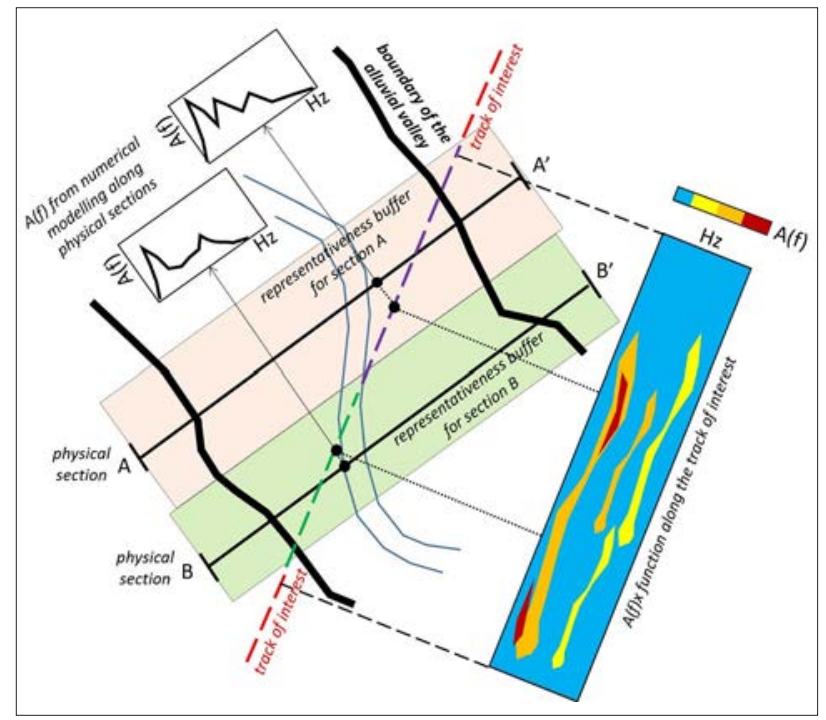

Figure 10. Sketch illustrating the solution used to extrapolate the amplification functions (A(f)) from $2 \mathrm{D}$ numerical simulations along several cross sections that are oriented transverse to the alluvial valley to a line of interest (LIn) that crosses the valley in a generic direction. The $\mathrm{A}(\mathrm{f})_{\mathrm{x}}$ distribution along the line is the transposition of several punctual $A(f)$ functions with physical meanings. processed data clearly show that the main vibration mode of the building is very close to $0.6 \mathrm{~Hz}$; this peak is particularly intense on the roof of the tower (T1), but it is also visible with a lower amplitude on the middle floor (T2). The same peak is strongly attenuated at the ground floor, while a main peak (T3) is visible at approximately $1 \mathrm{~Hz}$, which is closer to the resonance mode of the alluvial fill measured at stations LV_10 and LV_11. A double seismic resonance effect [Chen and Scawthorn 2003] is therefore recognizable between the free-field site and the Eurosky Towers because the soil resonance frequency and the building's first vibration mode are very similar.

\section{Numerical modelling}

$1 \mathrm{D}$ and $2 \mathrm{D}$ numerical simulations were performed to define the LSR in terms of amplification function along the Via Laurentina, considering the geological setting of the site in terms of both the valley shape and the heterogeneity of the alluvial fill. The ancient Via Laurentina does not cross the alluvial valley in the direction in which the main 2D physical effect (i.e., the interaction between the soil resonance and the lateral waves from the sides of the valley) is expected [Bard and Bouchon 1985]. Therefore, 2D numerical modelling along the Via Laurentina cross section cannot be considered representative of the real $2 \mathrm{D}$ effects due to the physical interaction between the seismic waves and the valley system. Figure 10 shows the here proposed procedure for extrapolating the LSR from a series of physically-based transverse cross sections to a non-transverse one. Considering a generic alluvial valley and a line of interest (LIn) which is not normal to the valley's axis, it is possible to derive the $\left(\mathrm{A}(\mathrm{f})_{\mathrm{X}}\right)$ distribution of the $2 \mathrm{D}$ amplification functions along the LIn by modelling the $\mathrm{A}(\mathrm{f})$ along a series of

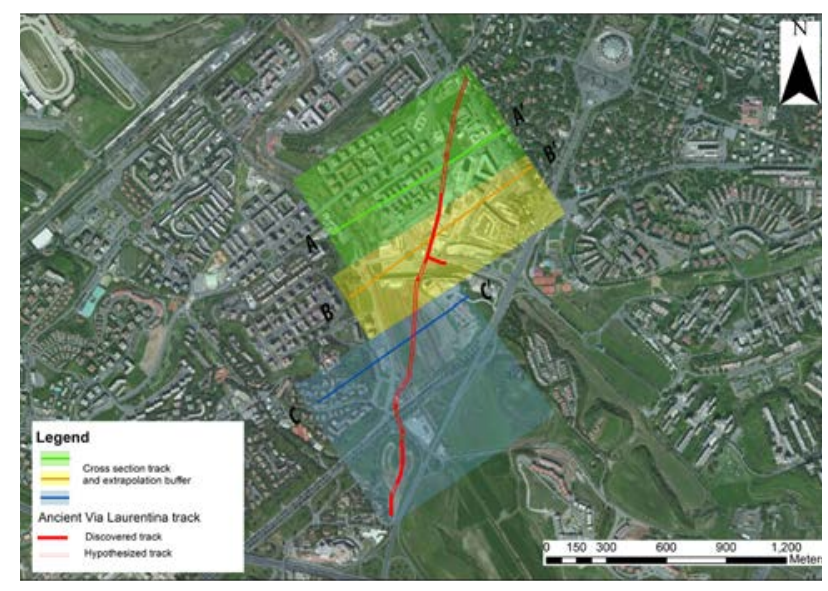

Figure 11. Route of the ancient Via Laurentina and reliable geological buffers, which include the three cross sections that were used for the 2D numerical modelling. 


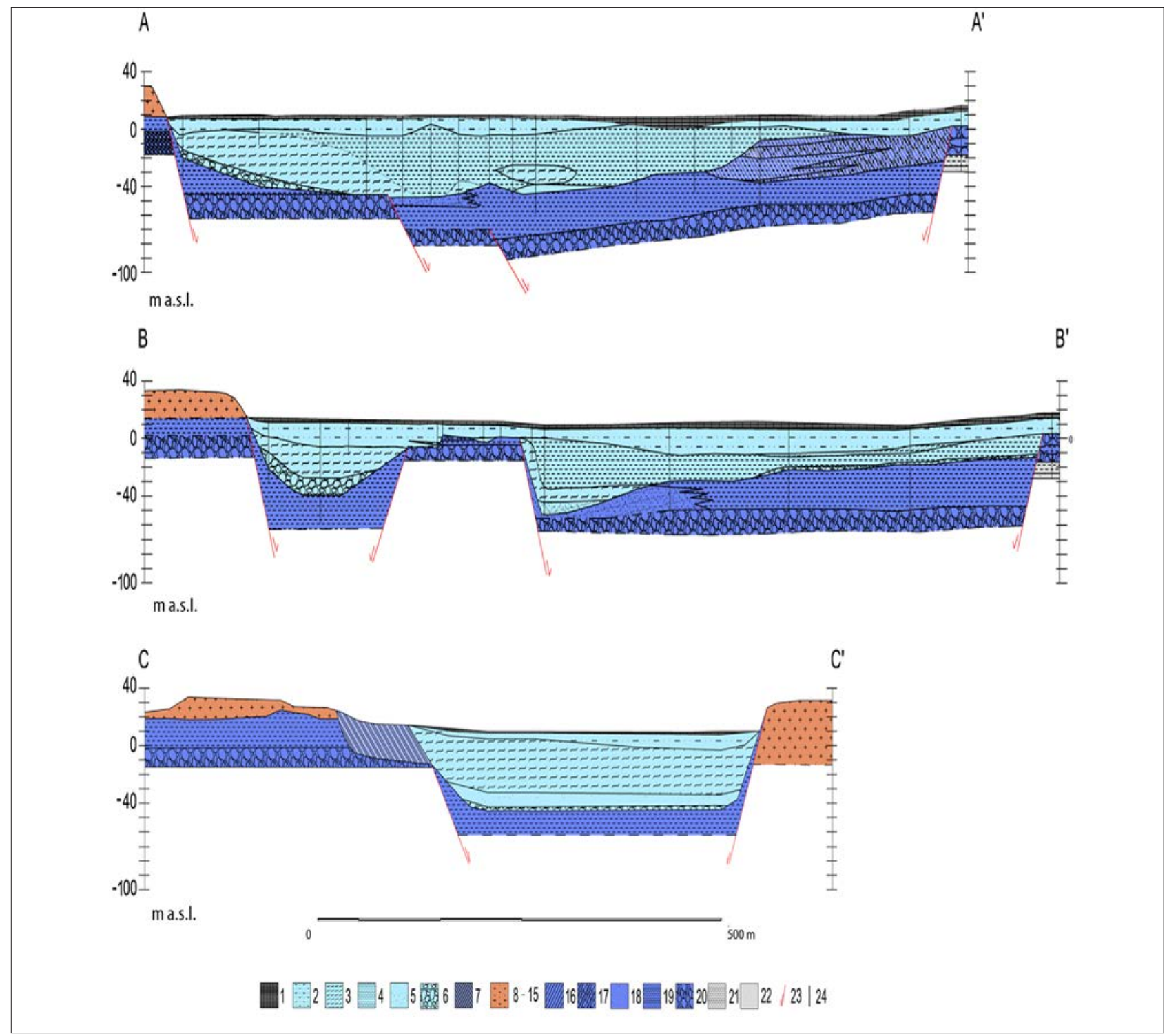

Figure 12. Geological cross sections along AA', BB', CC' in Figure 11. See Figure 4 for the key to the legend.

cross sections that are normal to the axis of the valley. The $A(f)$ functions that are modelled along each cross section can be transposed (through an orthogonal projection) to the LIn if the corresponding projections along Lin is inside the representative buffer of the cross section; otherwise, a different cross section is used to perform the transposition. The width of the representative buffer, and thus the number of physical transverse sections required, depends on the local geological setting. The resulting $A(f)_{x}$ function is formed along the LIn even though it derives from $2 \mathrm{D}$ models that are developed along different cross sections; in this way, the final solution merges the physical effects due to the seismic response of the natural system (valley) with the engineering-geological model of the subsoil. Following this approach, in our geological reconstruction of the geological setting of the valley, the route of the ancient Via Laurentina has to be included in three geological buffers respectively including a transversal section (Figure 11). The three geological sections are representative of the lithological and stratigraphic setting of the ancient Via Laurentina and highlight the geological peculiarities of the valley. Section AA' (Figure 12 , top) represents the geological setting of the western portion of the ancient Via Laurentina and is used to simulate the presence of a landslide in the western portion of the Fosso di Vallerano Valley. Section BB' (Figure 12, middle) crosses the valley in the middle portion and is representative of the structural setting of the area; i.e., it highlights the presence of the buried horst in the central portion of the valley [Bozzano et al. 2016]. Finally, the geological section CC' (Figure 12 bottom) characterizes the southern part of the ancient Via Laurentina and is used to simulate the area that is characterized by volcanic deposits and the transition towards the valley. The $1 \mathrm{D}$ and $2 \mathrm{D}$ modelling 


\begin{tabular}{lccc}
\hline Litotechnical unit & $\begin{array}{c}\gamma \\
\left(\mathbf{k N} / \mathbf{m}^{\mathbf{3}}\right)\end{array}$ & $\begin{array}{c}\text { Vs } \\
(\mathbf{m} / \mathbf{s})\end{array}$ & $\begin{array}{c}\mathbf{D} \\
(\mathbf{\%})\end{array}$ \\
\hline AL-AF & 17.0 & 118 & 1 \\
AL-VSC & 16.5 & 225 & 1 \\
AL-CL & 18.3 & 235 & 2 \\
Al-PC & 17.2 & 150 & 3 \\
AL-GR & 21.0 & 713 & 1 \\
AL/PT-SD & 19.2 & 417 & 1 \\
PT-CL & 18.3 & $650-357$ & 3 \\
PT-LS(CL) & 18.3 & 250 & 3 \\
PT-LS(GR) & 21.0 & 550 & 3 \\
VC & 17.5 & 550 & 2 \\
LA & 27.0 & 850 & 1 \\
FL & 19.2 & 450 & 1 \\
Seismic bedrock & 22.0 & $750-1100$ & 1 \\
\hline
\end{tabular}

Table 1. Parameter values attributed to the lithotecnical units reported in Figure 4 according to Bozzano et al. [2016]. ( $\gamma$ : weight per unit volume; Vs: S wave velocity; D: damping).

were performed by attributing the parameter values proposed by Bozzano et al. [2016] to the lithotecnical units and by assuming visco-elastic conditions with the damping distribution shown in Table 1. As reported by Bozzano et al. [2016] the attribution of dynamic properties to the subsoils of the Fosso di Vallerano valley was derived at a single location and seismometric records were used to calibrate the local seismo-stratigraphy taking into account the available high-resolution engineering-geological model of the local subsoil.

A total of 27 soil profiles, representative for the different geological conditions along the ancient Via Laurentina were selected for the 1D numerical models, and the respective amplification functions were calculated using the free software STRATA [Kottke and Rathje 2008]. The main resonance frequencies resulting by the modelling along this section are in good agreement with the ones measured. The highest amplification values (i.e., up to 6) of the modelled $A(f)$ functions are located in the central portion of the ancient Via Laurentina, which corresponds to the deepest part of the Fosso di Vallerano Valley in the frequency range of $0.7-1.4 \mathrm{~Hz}$. This is due to the impedance contrast between the alluvial deposits and the basal gravels (unit AL-GR; Table 1), which represents the local seismic bedrock [Bozzano et al. 2016]. In areas of shallow seismic bedrock (i.e., in the central part of the route; Figure 4) as well as near the external portions of the buried sides of the valley, the main amplification values are in the higher frequency range $(2-4.6 \mathrm{~Hz})$. In the southern part of the ancient Via Laurentina (near the Pontina archaeological site), the outcrops of volcanic rocks that overlie the basal gravels explain the absence of amplification effects. To obtain a $\mathrm{A}(\mathrm{f})_{\mathrm{x}}$ distribution of the 1D functions that were modelled along the route (Figure 13), these functions were interpolated using Kriging considering 52 functions (27 simulated and 25 extrapolated assuming constant geological conditions) with an average spacing of $40 \mathrm{~m}$.

The $2 \mathrm{D}$ models were performed using the CESAR-LCPC code [Humbert et al. 2005] based on the Finite Element Method (FEM) and assuming the same conditions that were used for the 1D simulations. The geological cross sections were discretized using a triangular mesh with linear interpolation; the size of the elements was chosen according to the Equation (1):

$$
\Delta h=\frac{\lambda}{12}
$$

where $\lambda=$ the wavelength, and $\Delta h=$ the element size.

Considering the lowest $S$ wave velocity of the alluvial deposits $(118 \mathrm{~m} / \mathrm{s})$ and the highest $S$ wave velocity of the seismic bedrock $(1100 \mathrm{~m} / \mathrm{s})$, element sizes of $1 \mathrm{~m}$ for the alluvial deposits and $10 \mathrm{~m}$ for the seismic bedrock were chosen to allow for reliable numerical solutions up to $10 \mathrm{~Hz}$. The same weak motion that was used in the 1D simulation was applied as a shear wave $(\mathrm{SH})$ for the displacements at the bedrock level. Fixed boundary conditions were applied to the model boundaries; i.e., the degrees of freedom of each node in the mesh are equal to zero, which means that no movement (horizontal or vertical) is allowed. The numerical A(f) functions were obtained by considering the spectral ratio between the signals in the valley and the input recorded at the outcropping seismic bedrock (point $\mathrm{R}$ in Figure 7) [Borcherdt 1994]. The resulting amplifica- 


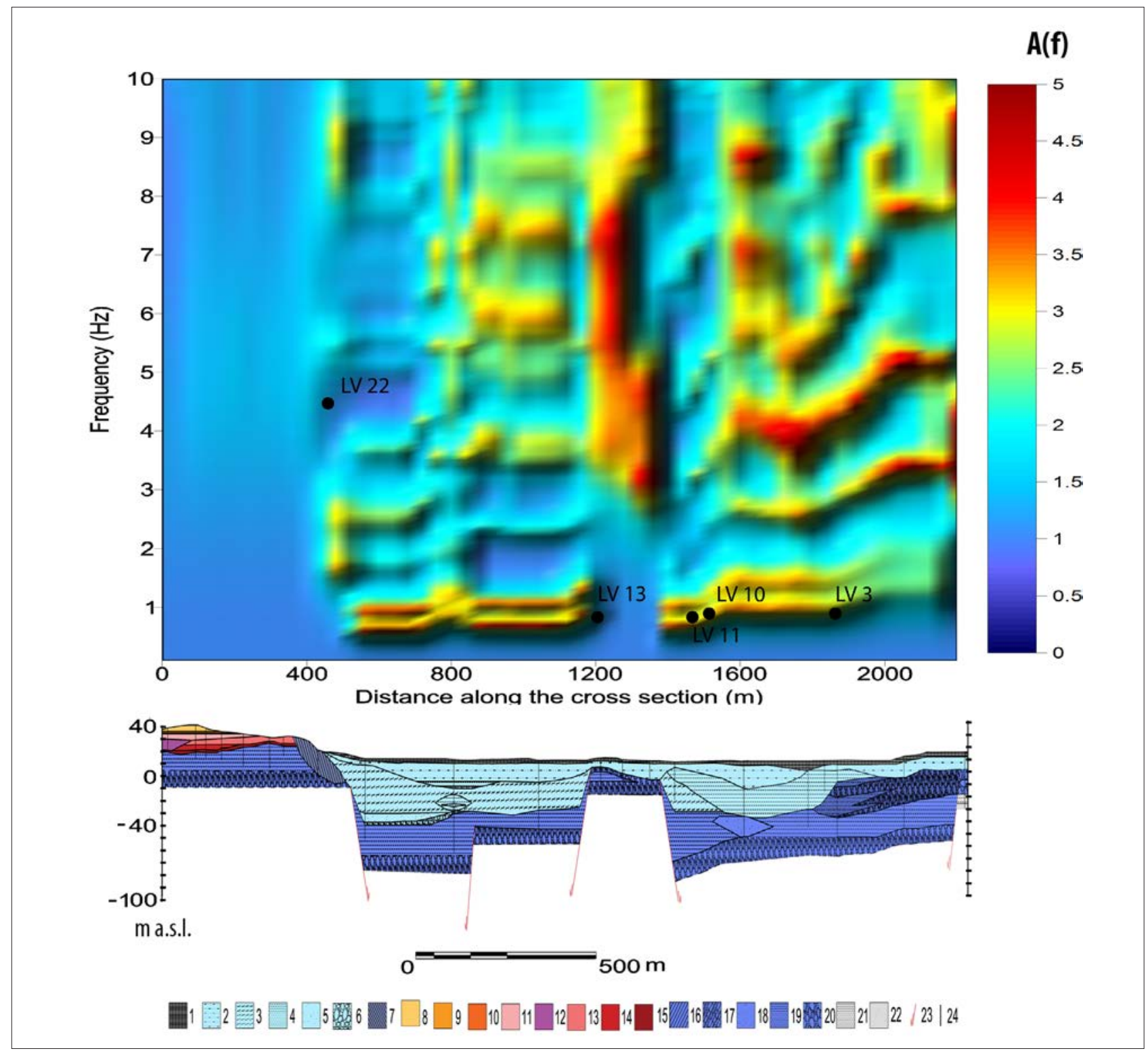

Figure 13. 1D A(f) distribution (top) along the route of Via Laurentina (bottom). See Figure 4 for the key to the legend. Location of noise measurements along the route (and related first $\mathrm{H} / \mathrm{V}$ peak) is also reported.

tion functions were interpolated with Kriging to obtain the $A(f)_{x}$ distribution, which can be compared with the distribution obtained from the 1D modelling (Figure 14). The modelling results show a significant resonance peak at 0.7 to $1.4 \mathrm{~Hz}$ where the ancient Via Laurentina crosses the deepest part of the Vallerano Valley, while the frequency of the first resonance mode increases to 2.5 $\mathrm{Hz}$ where the seismic bedrock is shallower (i.e., corresponding to the horst in the middle portion of the route). It is worth noting that the $\mathrm{A}(\mathrm{f})$ values are greater in the $2 \mathrm{D}$ results than in the $1 \mathrm{D}$ results, and the frequencies that correspond to the higher resonance modes are different. These results demonstrate the non-negligible role of $2 \mathrm{D}$ effects on the LSR in the Fosso di Vallerano Valley. To quantify the differences between the $2 \mathrm{D}$ and 1D outputs and highlight where the former are better than the latter, an aggravation factor $A_{a g}(f)_{x}$ was derived according to the Equation (2):

$$
A_{a g}(f)_{x}=\frac{A(f)_{x} 2 D}{A(f)_{x} 1 D}
$$

The $\mathrm{A}_{\mathrm{ag}}(\mathrm{f})_{\mathrm{x}}$ distribution along the route of the $\mathrm{Via}$ Laurentina (Figure 15) in this case was also obtained using a Kriging interpolator.

The analysis of the $A_{a g}(f)_{x}$ distribution shows that the $2 \mathrm{D}$ effects cannot be neglected along the entire route of the Via Laurentina (Figure 15). In particular, several $A_{a g}(f)$ values up to 2 indicate that the $2 \mathrm{D} \mathrm{A}(\mathrm{f})$ value is twice that of the $1 \mathrm{D}$ value (Figure 15). Nevertheless, it is worth noting that this evidence does not include the first resonance frequency $(0.8 \mathrm{~Hz})$ but only 


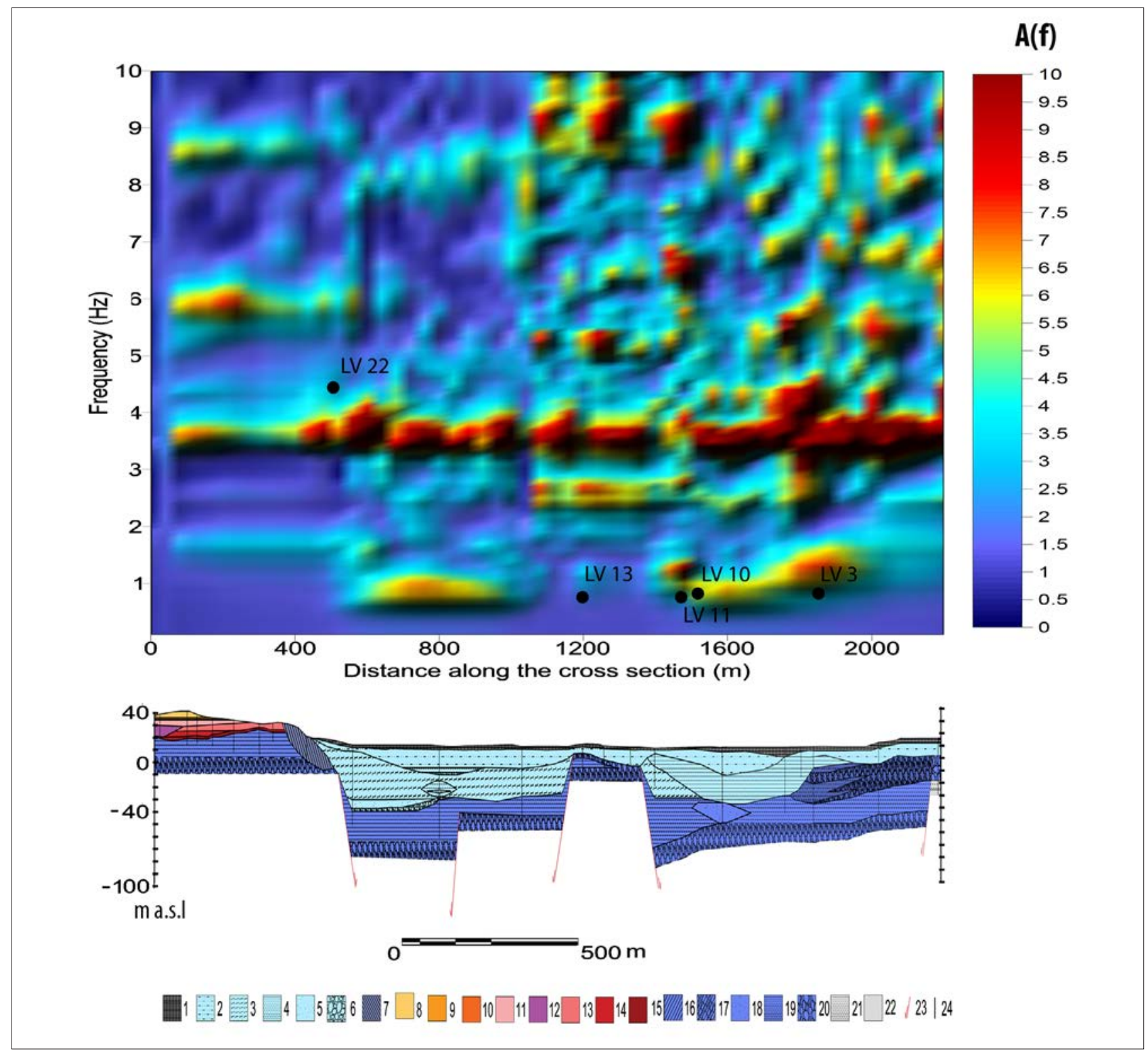

Figure 14. 2D A(f) $)_{x}$ distribution (top) along the ancient route of Via Laurentina (bottom). See Figure 4 for the key to the legend. Location of noise measurements along the route (and related first $\mathrm{H} / \mathrm{V}$ peak) is also reported.

higher resonance modes, (i.e., 3.5, 6, and $8.5 \mathrm{~Hz}$ ), which may be of interest for buildings or infrastructure.

The comparison between the normalized acceleration response spectra (elastic condition at a $5 \%$ of damping), which result from $1 \mathrm{D}$ and 2D modelling (Figure 16), outputs a general good fit in terms of spectral shape even if some specific difference can pointed out:

- 1D response spectrum are generally more conservative than the $2 \mathrm{D}$ ones (b, $\mathrm{c}$ and $\mathrm{e}$ in Figure 16);

- 1D stratigraphic effects are prevalent out of the valley ( $a$ and $f$ in Figure 16);

- 2D amplifications are prevalent close to the sides of the valley ( $d$ in Figure 16) and they are responsible for higher response spectrum values respect to the $1 \mathrm{D}$ models, especially at the lowest periods (i.e. $<0.5 \mathrm{~s}$ ).

\section{Conclusions}

This study presents $2 \mathrm{D}$ modelling of the LSR along a reference line that is generically oriented with respect to a natural valley system. The ancient Roman Via Laurentina road was considered because it has been excavated over the last decade in the Fosso di Vallerano Valley, which is located south of the historical centre of Rome, during the construction of the "Europarco business Park". Many specific directives have been issued regarding the insertion of the ancient road into the present urban fabric (excluding the remains that were found beneath the modern road network) to preserve its structures and to make it visible at the surface. In particular, the urban plan in the Fosso di Vallerano Valley has been modified, including changes to the locations of the construction sites and the align- 


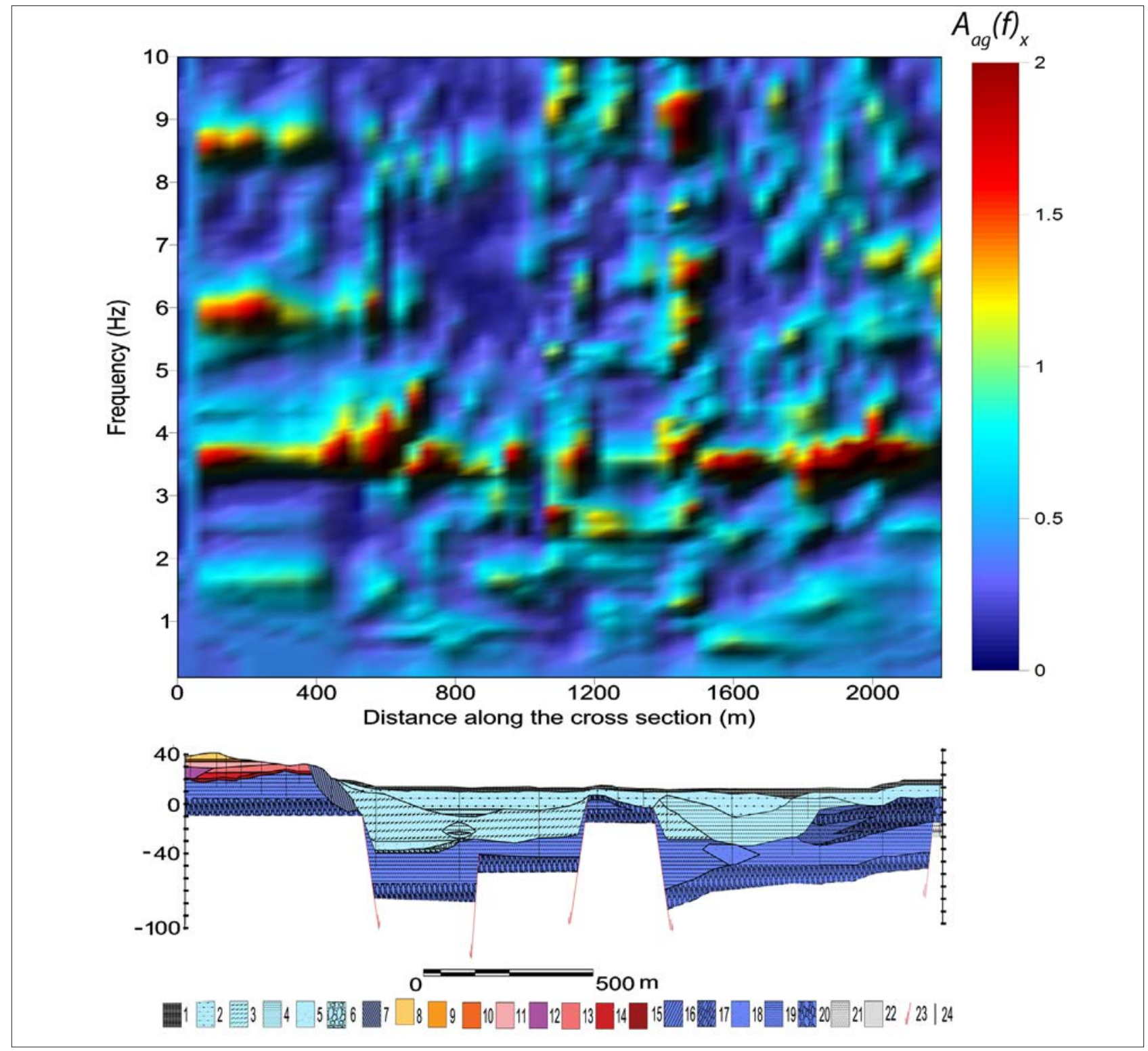

Figure 15. $A_{a g}(f)_{x}$ distribution (top) along the ancient Via Laurentina (bottom). See Figure 4 for the key to the legend.

ment of the Eurosky Towers with the ancient road. The remains could not be preserved at their original levels due to the substantial increases in the surface water system and the water table and the presence of modern structures. Therefore, the road and monumental structures were adequately protected and covered with soil, and their presence was marked at the surface by lawns that reproduce their plans and are visible within the new central pedestrian square. A route with information about the topography of the area and the use of the ancient structures was also created. The urban plan of the Pontina site was also modified to include provisions for preserving the road within the original cut in a private garden with a solution that allows the visualisation of the Castellaccio tower's skyline, which reproduces the line of the ancient road.
To account for the physical interaction of the valley system with the seismic waves (i.e., to consider the effects related to the valley shape and the heterogeneity of the alluvial deposits), three $2 \mathrm{D}$ cross sections were modelled, and the results were transposed to the route of the ancient Via Laurentina by projecting the obtained amplification functions $(\mathrm{A}(\mathrm{f}))$. An engineering-geological criterion was applied to verify the reliability of the performed projection within a representative buffer. The derived $A(f)_{x}$ distribution is physically based and geologically constrained. A comparison with the results of $1 \mathrm{D}$ modelling demonstrates that the $2 \mathrm{D}$ effects are not negligible in the study area. Moreover, the obtained $A(f) x$ distribution is reliable for evaluating the expected seismic amplification at the foundations of new buildings (i.e., the Eurosky Towers) that have been designed also to preserve the archaeological site 


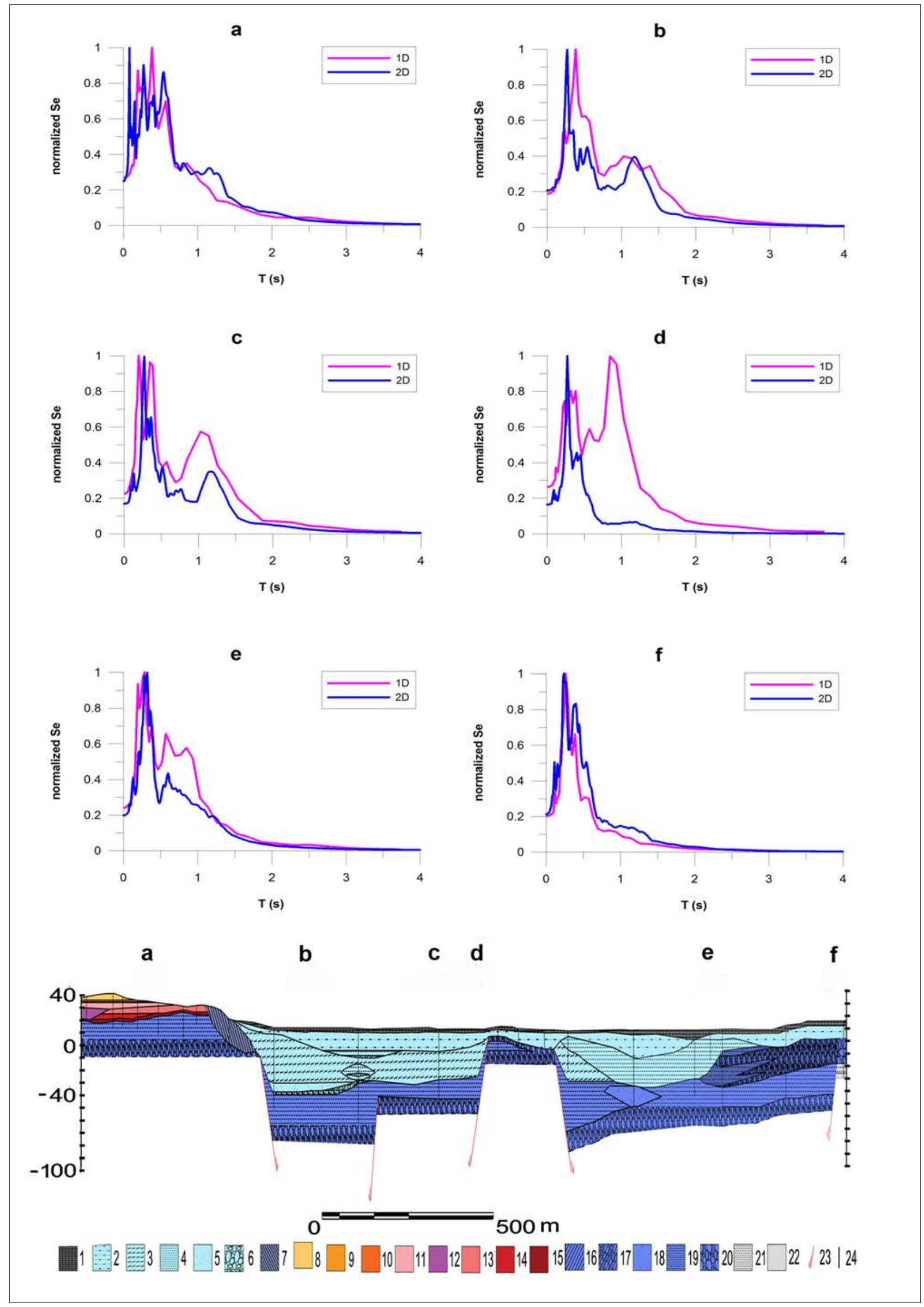

Figure 16. Comparison between $1 \mathrm{D}$ and 2D normalized response spectra in different position along the ancient route of Via Laurentina (bottom). See Figure 4 for the key to the legend. 
and are therefore aligned with the route of the ancient Roman road. 1D and/or 2D numerical models can be regarded as suitable for designing linear structures or infrastructure (e.g., bridges, aqueducts or viaducts) as well as for analysing the LSR of similar archaeological remnants.

Acknowledgements. This paper reports preliminary results of Ph.D. research at the Department of Earth Sciences of the "Sapienza" University of Rome (Chiara Varone, PhD Student). The authors wish to thank L. Lenti, Ph.D., the University Paris-Est LCPC and IFSTTAR (French Institute of Science and Technology for Transport, Development and Networks), who allowed the use of the CESAR - LCPC software for the $\mathrm{PhD}$ research.

\section{References}

Ascani F., Bozzano F., Buccellato A., Del Monte M., Matteucci R., Vergari F. (2008) - Evoluzione del paesaggio e antiche vie di drenaggio nell'area de "Il Castellaccio” (Roma) da indagini geologiche, geomorfologiche e archeologiche. In Geologica Romana 41:55-77.

Bard, P.Y. and M. Bouchon (1985). The two-dimensional resonance of sediment-filled valleys, Bull. Seismol. Soc. Am. 75, 519-541.

Bonadonna F.P. (1968). Studi sul Pleistocene del Lazio. V. La Biostratigrafia di Monte Mario e la "Fauna Malacologica Mariana” di Cerulli-Irelli. Mem. Soc. Geol. It., 7, 261-321.

Borcherdt, R.D. (1994). Estimantes of site-dependent response spectra for design (methodology and justification), Earthq. Spectra 10, 617-653.

Bozzano, F., Caserta A., Govoni A., Marra F. and S. Martino (2008). Static and dynamic characterization of alluvial deposits in the Tiber River Valley: New data for assessing potential ground motion in the City of Rome. Journal of Geophysical Research, 113, B01303.

Bozzano, F., Martino, S., Giacomi, A.C., Lenti, L., Martini, G. and M.P. Santisi D’Avila, (2012). Numerical modeling of nonlinear dynamic shear strains in heterogeneous soils by 1D-3C finite difference SWAP. Proc. 15 World Conference on Earthquake Engineering, 24-28 September 2012, Lisboa, paper 0427.

Bozzano, F., Marra F., Martino S., Paciello A., Scarascia Mugnozza G., and C. Varone (2015). The local seismic response of the Fosso di Vallerano valley (Rome, Italy) based on a high-resolution geological model. Rend. Online Soc. Geol. It., 35, 29-32.

Bozzano, F., Lenti, L., Marra, F., Martino, S., Paciello, A, Scarascia Mugnozza, G. and C. Varone (2016). Seismic response of the geologically complex allu- vial valley at the "Europarco Business Park" (Rome - Italy) through instrumental records and numerical modelling. Italian Journal of Engineering Geology and Environment., 16(1), 37-55.

Buccellato, A. (2005). Laurentina via, Lexikon Topographicum Urbis Romae III, Roma, 213-27.

Buccellato, A. (2007). L'antica via Laurentina: l'arteria e le infrastrutture. Fasti On Line, Folder 88.

Buccellato, A. and Coletti, F. (2013). Resti di un tabernacolo privato e di un ripostiglio monetale da un edificio presso la via Laurentina antica (scavi 2007). In M. Barbera (ed.), Costantino 313, Roma, 67-69.

Caserta, A., Martino, S., Bozzano, F., Govoni, A. and F. Marra (2012). Dynamic properties of low velocity alluvial deposits influencing seismically-induced shear strains: the Grottaperfetta valley test-site (Rome, Italy), Bull Earthquake Eng, 10, 1133-1162.

Chen W., C. Schawthorn (2003). Earthquake Engineering handbook.

Conato V., Esu D., Malatesta A. and F. Zarlenga (1980). New data on the Pleistocene of Rome. Quaternaria. Storia Naturale e Culturale del Quaternario Roma, (22), 131-176.

Cosentino D., Cipollari P., Di Bella L., Esposito A., Faranda C., Giordano G., Gliozzi E., Mattei M., Mazzini I., Porreca M. and R. Funiciello (2009). Tectonics, sea-level changes and palaeoenvironments in the early Pleistocene of Rome (Italy). Quaternary Research, 72 (1), 143-155, doi:10.1016/j. yqres.2009.03.003.

Del Monte M., D’Orefice M., Luberti G.M., Marini R., Pica A. and F. Vergari (2016). Geomorphological classification of urban landscapes: the case study of Rome (Italy). Journal of Maps, 1-12, 1 pls, doi: $10.1080 / 17445647.2016 .1187977$

Florindo F., Karner D.B., Marra F., Renne P.R., Roberts A.P. and R. Weaver (2007). Radioisotopic age constraints for Glacial Terminations IX and VII from aggradational sections of the Tiber River delta in Rome, Italy. Earth and Planetary Science Letters, 256, 61-80, doi: 10.1016/j.epsl.2007.01.014.

Gaeta M., Freda C., Marra F., Arienzo I., Gozzi F., Jicha B. and T. Di Rocco (2016). Paleozoic metasomatism at the origin of Mediterranean ultrapotassic magmas: constraints from time-dependent geochemistry of Colli Albani volcanic products (Central Italy). Lithos, 244, 151-164, doi:10.1016/j. lithos.2015.11.034.

Humbert P., Fezans G., Dubouchet A. and D. Remaund (2005). CESAR-LCPC: A computing software package dedicated to civil engineering uses. 
Bullettin del Laboratoires des Ponts et Chaussée, 256/257: 7-37.

Karner D.B. and F. Marra (1998). Correlation of fluviodeltaic aggradational sections with glacial climate history: A revision of the Pleistocene stratigraphy of Rome. Geological Society of America Bulletin, 110, 6, 748-758.

Karner D. B. and P.R. Renne (1998) . 40Ar/39Ar geochronology of Roman volcanic province tephra in the Tiber River valley: Age calibration of middle Pleistocene sea-level changes. Geological Society of America Bulletin, 110, 6, 740-747.

Karner D.B., Marra F., Florindo F. and E. Boschi (2001). Pulsed uplift estimated from terrace elevations in the coast of Rome: evidence for a new phase of volcanic activity? Earth and Planetary Science Letters, 188, 135-148.

Konno, K. and Omachi, T., (1998). Bull. Seism. Soc. Am., 88, 228-241.

Kottke, Albert R., and M.E. Rathje (2008). Technical Manual for Strata. PEER Report 2008/10. University of California, Berkeley, California.

Mancini M., Moscatelli M., Stigliano F., Cavinato G.P., Milli S., Pagliaroli A., Simionato M., Brancaleoni R., Cipolloni I., Coen G., Di Salvo C., Garbin F., Lanzo G., Napoleoni Q., Scarapazzi M., Storoni Ridolfi S. and R. Vallone (2013). The Upper Pleistocene-Holocene fluvial deposits of the Tiber River in Rome (Italy): lithofacies, geometries, stacking pattern and chronology. Journal of Mediterranean Earth Sciences, Special Issue, 95-101.

Marra F. (1993). Stratigrafia e assetto geologico-strutturale dell'area romana tra il Tevere e il Rio Galeria. Geologica Romana, 29, 515-535.

Marra F. and C. Rosa (1995). Stratigrafia e assetto geologico dell'area romana - In: La geologia di Roma: il centro storico. Mem. descr. Carta Geol. d’It., 50, $49-118$.

Marra F. and F. Florindo (2014). The subsurface geology of Rome: sedimentary processes, sea-level changes and astronomical forcing. Earth - Science Reviews, 136, 1 - 20, doi: 10.1016/j.earscirev.2014.05.001.

Marra F., Florindo F. and D.B. Karner (1998). Paleomagnetism and geochronology of early Middle Pleistocene depositional sequences near Rome: comparison with the deep sea $\delta^{18} \mathrm{O}$ climate record. Earth Planet. Sci. Lett., 159, 147-164.

Marra F., Florindo F. and E. Boschi (2008). History of glacial terminations from the Tiber River, Rome: Insights into glacial forcing mechanisms. Paleoceanography, 23(2), 1-17, doi:10.1029/2007PA001543.
Marra F., Karner D.B., Freda C., Gaeta M. and P.R. Renne (2009). Large mafic eruptions at the Alban Hills Volcanic District (Central Italy): chronostratigraphy, petrography and eruptive behavior. Journ. of Volc. and Geoth. Res., 179, 217-232, doi:10.1016/j.jvolgeores.2008.11.009.

Marra F., Bozzano F. and F.R. Cinti (2013). Chronostratigraphic and lithologic features of the Tiber River sediments (Rome, Italy): implications on the post-glacial sea-level rise and Holocene climate. Global and Planetary Change, 107, 157-176, doi:10.1016/j.gloplacha.2013.05.002.

Marra F., Sottili G., Gaeta M., Giaccio B., Jicha B., Masotta M., Palladino D.M. and D. Deocampo (2014b). Major explosive activity in the Sabatini Volcanic District (central Italy) over the 800-390 ka interval: geochronological - geochemical overview and tephrostratigraphic implications. Quaternary Science Reviews, 94, 74-101, doi:10.1016/j.quascirev.2014.04.010.

Marra F., Rohling E.J., Florindo F., Jicha B., Nomade S., Pereira A. and P.R. Renne (2016a). Independent $40 \mathrm{Ar} / 39 \mathrm{Ar}$ and $14 \mathrm{C}$ age constraints on the last five glacial terminations from the aggradational successions of the Tiber River, Rome (Italy). Earth Planet Sci. Lett., in press., http://dx.doi.org/10.1016/j. epsl.2016.05.037.

Martino S, Lenti L, Gelis C, Giacomi AC, Santisi D’Avila P, Bonilla F, Bozzano F, Semblat JF (2015). Influence of lateral heterogeneities on strong motion shear strains: simulations in the historical center of Rome (Italy). BSSA, 105(5):2604-2624. doi:10.1785/0120140180.

Milli S., D’Ambrogi C., Bellotti P., Calderoni G., Carboni M. G., Celant A., Di Bella L., Di Rita F., Frezza V., Magri D., Pichezzi M.R. and V. Ricci (2013). The transition from wave-dominated estuary to wave-dominated delta: the Late Quaternary stratigraphic architecture of Tiber River deltaic succession (Italy). Sedimentary Geology, 284-285, 159-180.

Nakamura, Y. (1989). A method for dynamic characteristics estimation of subsurface using microtremors on the ground surface. Quaterly Rept. RTRI, Jpn, 30, 25-33.

Parotto M. and A. Praturlon (1975). Geological summary of the Central Apennines. In: Structural Model of Italy. Maps and Explanatory Notes. Quaderni della Ricerca Scientifica, 90, 257-311.

Rovelli, A., Caserta, A., Malagnini, L. and F. Marra (1994). Assessment of potential strong motions in the city of Rome, Ann. Geofisc. 37: 1745-1769. 
Rovelli, A., Malagnini, L., Caserta, A. and F. Marra (1995). Using 1-D and 2- D modelling of ground motion for seismic zonation criteria: Results for the city of Rome, Ann. Geofisc. 38: 591- 605.

Sani F., Del Ventisette C., Montanari D., Coli M., Nafissi P. and A.Piazzini (2004). Tectonic evolution of the internal sector of the Central Apennines, Italy. Marine and petroleum geology, 21 (10), 1235-1254, doi:10.1016/j.marpetgeo.2004.09.004.

SESAME (2004). Guidelines for the implementation of the $\mathrm{H} / \mathrm{V}$ spectral ratio technique on ambient vibrations. http://sesame.fp5.obs.ujf/grenoble.fr/ index.htm.

*Corresponding author: Chiara Varone,

Research Centre for Geological Risks (CERI), University of Rome "La Sapienza", Rome, Italy; email: chiara.varone@uniroma1.it 